\title{
Widowhood practices and the church in south-east Nigeria
}

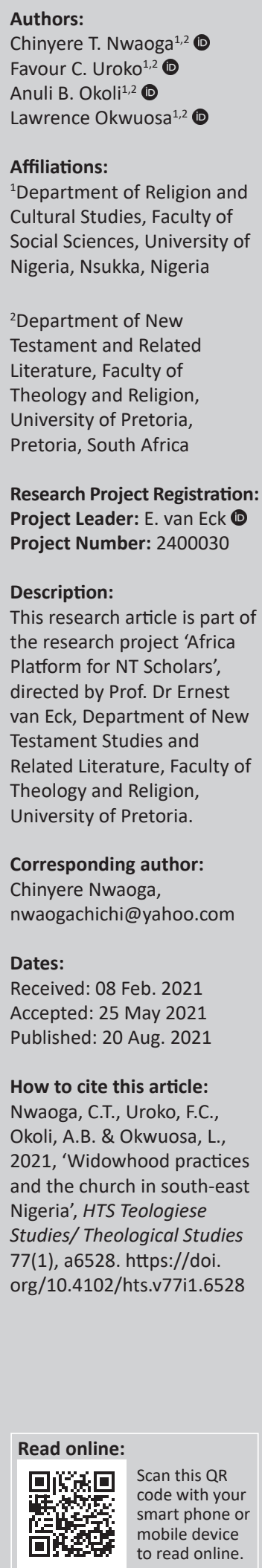

\begin{abstract}
Widowhood practice is an unjust cultural practice directed against women who lose their husbands. The effects of this long-time culture on society, especially women, are continuing even in the 21st century as a result of rules, laws and regulations, and cultural values that have been laid down by the ancestors and nurtured by subsequent generations. The findings of the research indicated that discriminatory widowhood practices were humiliating to women and were made by men to relegate women to the background. This article, therefore, studied this cultural practice in Igboland in order to create a niche for the church in its alleviation. Nevertheless, it is on record that Christian churches have made remarkable efforts to alleviate the plight of widows. However, a lot is still expected for the total eradication of this age-old tradition.
\end{abstract}

Contribution: The church has an enormous role to play in the fight against unjust cultural practices against women in Igboland. The church was chosen because of the respect that people of Igboland give to priests and other members of a religious community.

Keywords: widow; practice; church; women; gender.

\section{Introduction}

Discriminatory cultural practices are harmful traditional practices directed against women because of their sex. This is popular in south-east Nigeria. South-east Nigeria comprises Abia, Imo, Enugu, Anambra and Ebonyi states. Christianity is the major religion in the south-east and Igbo is the official language. South-east Nigeria is an area covering about $76358 \mathrm{~km}^{2}$ east of the lower Niger and south of the Benue valley. The region is located between latitudes 4 and 7 degrees north of the Equator and between longitudes 7 and 9 degrees east (Okali, Okpara \& Olawoye 2001:12). One of such discriminatory cultural practices that affects the lives and standard of living of women is widowhood practices. When the husband of a woman dies, she automatically becomes vulnerable to suffering the humiliating transformation into being a widow. Widowhood cultural practice is an unfair cultural practice against women especially when it hinders the rights of women. The United Nations presented the foremost official meaning of such violence in 1993. It was at this point that the general assembly of the United Nations adopted the declaration on the abolition of cruelty against women (World Health Organization 2020). According to Illika, Okonkwo and Adogu (2002:53-58), Article 1 of this declaration includes any violent act that is gender-biased inclined and it effects result in psychological, sexual or physical injury or pain to women. As a result of the cultural ritual, widows experience low self-esteem, cowardice, pain, discomfort, immobility and dependence on other people, which are the opportunity cost of widowhood. Almost all widows have weak personality variables that include anxiety, fear, easily dumbfounded, low self-esteem and inferiority complex. Women are always victims of these cultural practices and the perpetrators are men. The rules and regulations guiding the Igbo communities were made primarily by men and are handed down from generation to generation. Women accepted these rules because of fear of superstitious beliefs and traditions. Most times, women contribute a lot in promoting and supporting inhuman cultural practices.

Surprisingly, this practice is enforced through the activities of some women popularly known as Umuada. The activities of the Umuada are insensitive, harsh and negatively directed to their fellow women. This article adopted the historical and descriptive phenomenological methodology. It postulates that the society and social institutions have to contribute to make sure that unfair laws are abolished in south-eastern cultural milieu.

Copyright: () 2021. The Authors. Licensee: AOSIS. This work is licensed under the Creative Commons Attribution License. Note: Special Collection: Africa Platform for NT Scholars, sub-edited by Ernest van Eck (University of Pretoria). 


\section{General reputation of women in the church and society}

It is estimated that Nigeria has a population of over 140 million people (NBS 2006). This is notwithstanding the high level of irregularity that besieges census in Nigeria. Furthermore, there are many ethnic, tribal and religious groups in Nigeria. According to the International Institute for Democracy and Electoral Assistance (2000), there are approximately 250 languages and 2500 dialects in Nigeria. The major religions include Christianity, Islam and African traditional religion.

In Nigeria, female oppression has been traced back to the social structures in African traditional religion. Para-Mallam (2010:1) observed that apart from the social structures of African traditional religion, colonial patriarchy and global capitalism have escalated the oppression of women. Corroborating this idea, Rubenstein (2004:351) explained that women's contemporary social inferiority is a result of the inordinate influence of European colonialism, with its attendant gender-biased mechanism of patriarchal control.

In a similar observation, Nweze and Takaya (2001:19) revealed that the religious and cultural influences with regard to Islam from Arabia, Christianity from the Western world and indigenous belief, have continued to subject women to ridicule and oppression. In Islam, Barlas (2001:117) observed that women endure various forms of sexual disparity and discrimination, ranging from cultural mores, psychological attitudes, regulations that reject their recognition as legal and moral agents without their male counterparts, to the denial of their political and economic rights. Also, in Islam, men are in charge of women in the society, home and mosque because of the fact that Allah has enabled men to compete and dominate women (Orjinta 2011:9). Adamu (1999:57) concluded that Muslim women activists are seriously tackling issues of cultural and religious laws as it concerns the generality of Muslim women.

In the Nigerian churches, women are perceived as secondclass citizens. Most churches used Paul's letter to the Corinthians and to Timothy to silence women. In these epistles, Paul motioned that women are silent in the church and say nothing (1 Cor 14:34) and also that women should never teach and exercise any authority over men, insisting that the place of women is quietness (1 Tm 2:1). This has caused Christian men to abuse their wives, molest them and inflict physical and psychological injuries on them, insisting that they must be silent in accordance with the doctrine of God. In order not to be considered as promoting patriarchy, Paul in Galatians 3:28 projected that there is no distinction between the man and the woman, because they are one in Christ.

\section{Widowhood practices in Igboland}

A widow is a woman whose husband is dead and has not remarried. Odunze (2005:15) described widowhood as an unwanted and horrible period that women pass through in life. Widowhood is an awful period for any woman whose husband has died. A lot of stress and punishment are meted out to the woman as soon as her husband is pronounced dead. In Igboland, hardly can a man die and his kinsmen will accept that he died a natural death. The automatic perception is usually that the wife has killed him. The widow is treated worse than a murderer. She undergoes certain rituals in order to appease the dead husband and the spirits of the forefathers.

According to Ntozi (1997:23) in Amalu (2013:43), widowhood is a route that is branded by some inordinate customs and traditions, enforced melancholic lifestyles, social exclusion, denial of rights, extreme neglect, social oppression and psychological depression, amongst others. Nwadinobi (2001:5) added that at the death of the spouse, the widow is dethroned, defaced and disinherited. This means that in Igboland, as soon as the husband dies, the woman loses all her worth. Her dignity is believed to be the husband and once the husband is dead, the dignity crumbles. This is why Njaka (1975:22) maintained that widowhood practices remain the most unjust cultural practices that affect women in Igboland. Most of the traditions performed by women when their husbands die are dehumanising and have a negative influence on their lives. Onuogu (2007:106) observed that during the pre-Christian period, the treatment of widows differed based on the customs of their various communities. Every widow then, no matter the community in south-east Nigeria, is meant to observe the ritual cleansing.

According to Onyekwu in Amalu (2013:45), there are discriminations in the behaviours towards widows, depending mostly on the social status of the widow. Firstly, the socio-economic status of the widows is carefully taken into consideration before a decision is taken on the processes that the widow will undergo. The factors that are considered include the economic status of the widows, educational background, the widow's relationship with her in-laws, and the relationship between the widow and her husband. Thus, these factors determine the level of stress that a widow undergoes in Igboland.

\section{Models of widowhood practices in south-east Nigeria}

There are several examples of abominable cultural practices in Igboland. They are given as follows:

- Drinking water that is used for washing the corpse of the husband: Some societies are so harsh that the widow is sometimes asked to drink the water used for bathing the corpse of her husband to prove that she has no hand in his death.

- Widows are being ostracised: Widows suffer social isolation, which is a result of having removed women's ascribed social relations, or at least those relationships achieved early in life, such as marriage, whilst making other unavailable to them or training them to enter new social roles voluntarily. In Ebonyi State, a woman was 
asked to stay with her dead husband for a period of time to prove that she did not kill her husband. In Uzowani in Enugu State, a woman was chained during the burial ceremony of her husband. She was prevented from eating food and from taking baths until the funeral ceremony was over.

- Widows are forced to have sexual intercourse with strange men.

- Having asked to sit on a bare floor throughout the mourning period: In some parts of Uzuwani in Enugu State, the woman's hand is tied to her back like a thief and the first 28 days of mourning is usually the worst. The widow is expected to cry often to signify that she is missing her husband.

- Widows are not allowed to go to the market during mourning.

- Widows are not allowed to shave their pubic hair during the period of mourning in Igboland. They are kept in an unhygienic environment. They are not meant to look neat so as not to attract other men. According to Njaka (1975:17), this is a pan Igbo custom that has been practiced for a long time. As it stands now, widows can now take adequate care of themselves such as having access to good hospitals without being subjected to die at home.

\section{Factors responsible for discriminatory cultural practices against women}

Generally, African women are presented as inferior people who are only good at childbearing and cooking. According to the given assertion, whilst African men play a dominant role in some spheres of social life such as farming, hunting, fishing and fighting for the survival of the society, the role of women is limited to bearing children which depends on men to fulfil their requirements.

Consequently, Africans believe in the superiority of a male child and regard the female child as inferior. As portrayed by Eudora (2012:76), one of the factors that promoted the unjust cultural practice against women is the anti-colonial mindset that gave women less power in governance dominated by men. When the Europeans first visited African territory in the early 16th and late 17th century, their resurgence of interest and pride in African indigenous institutions came with the philosophy of negligence on women and they provided authority to men alone. The attitude of giving power only to men created inequality amongst men and women. In support of this fact, Hafkin and Bay (1976:4) put it as follows: 'in the time of the coming of the Europeans in African soil, power of authority and governance were concentrated on men alone'. Hence, the existing subordination of women is a resultant effect of colonial practices, mainly the bourgeois male chauvinist conjectures of European colonial administrators. This is replicated in the structure of Western education and Western Christian religion (Ehirim 2007:1). The missionaries tried to bridge the gap through the education of both men and women. It is pertinent to state that in Nigerian society, the physical strength of men is promoted to the detriment of women. In the traditional setting and biological nature of human beings, men are more physically strong than women. Therefore, men can easily beat up their wives and girlfriends and send them packing if they chose to do so. Women, on the other hand, are considered as the weaker sex who have no option other than to succumb to men's pressure because if the two should engage in a physical fight, the man is likely to win the battle. But not in all cases, because Christianity and Western education have taught men to be responsible husbands.

The issue of men being stronger than women when it comes to physical strength portrays the reason that no matter what a woman intends to possess, such a woman would, later on, be controlled by a man, otherwise the woman may be physically abused. Hence, the act of men possessing physical strength has weakened a woman, whilst a man is expected to use his physical power against a woman who proves to be stubborn or rude.

In virtually every male-dominated society, men are given more power and influence than women. Such influence allows men to marry more than one woman (polygamy) but a woman cannot marry two men (polyandry). Consequently, men now use their power to intimidate women and make them obey cultural laws all in the name of societal laws.

Hence, the nature and influence given to men especially in African society create the disparity between men and women where power is meant to favour men and women are inferior. In some African societies such as Nigeria, Ethiopia, Gambia, Senegal and Namibia, men are given more influence and they adopt polygamy. On the other hand, women are meant to marry one husband and stick to the man until death does them apart.

The societal perception of women as citizens of their community seems to be on the negative side. Generally, every society has a way of perceiving women in its domain. But for African societies and Igbo community, in particular, women are usually maltreated by men without complaint. In the traditional Igbo society, it is taboo for a menstruating woman to cook for a man. It is also taboo that a woman should give birth to twins as such woman will be ostracised, whilst the man who impregnated her will be absolved. In some societies such as Abakaliki, it is taboo for a woman to climb any tree, no matter what the condition. The same thing is applicable to societies such as Nnewi, Ozobulu, where no woman is allowed to climb a tree or cut a kola nut.

There is no community or nation without a culture of its own (Mbagwu 2009:11). Communities that happen to perceive their women positively are likely to protect their women with little marginalisation. But for communities that perceive their women negatively, there is a tendency to create suffering for their women. In Onitsha, for instance, women are given more power and are meant to participate in decision-making. 
Despite such powers and influence given to women, there is a belief that such women must respect their husbands or they will be sent packing. In some situations, especially when it comes to childbearing, a woman without a child is not accorded any respect; instead, she is regarded as a fool. In a situation where she does not bear a male child, she will not be allowed to have any share in the inheritance of the husband's compound.

However, in communities that perceive women negatively based on their gender, women will be marginalised and even ostracised for not knowing how to cook, not bearing a child, not having a male child, challenging the husband in a dispute, not cooking a meal on time, or for proving her husband wrong, therefore denying women the rights of ownership and inheritance (Bako \& Syed 2018:5).

\section{Implication of widowhood practices against women in Igboland}

The implication of widowhood against women in Igboland is nothing to write home about. There are psychological, social, economic and health implications of widowhood in Igboland. Saba (1997:41) reported that the effects of these harmful widowhood practices fall into three main categories: social, economic and emotional.

\section{Social implication}

Widows suffer social isolation as a result of having lost social relations. The death of a husband frequently results in family disorganisation, be it nuclear or extended family.

\section{Economic implication}

Economically, the widow is deprived of everything at the death of her husband. The high level of poverty in Igboland can be traced to some of the discriminatory cultural practices where women are prevented from doing certain jobs or activities that can help improve the economic condition of the people. For example, when a widow who is active is prevented from carrying some economic activities, it will reduce the income generation of the women and that of the society.

According to Unabuike (2009:52) the economic implications of the unjust cultural practices on women are seen in the high level of poverty. The economic hardship amongst women especially widows has forced many of them to resort to begging, sex work and other social vices in order to feed their families. Most of the time, the widow is deprived of her husband's landed property by the husband's relatives. These activities cause a lot of trauma to the widows involved.

Widowhood is a curse to education. The psychological trauma that a widow who is pursuing academic activities will not permit her to concentrate and reason accurately and some of them drop out of school because they don't have money to pay school fees and do other academic activities.

\section{Emotional implication}

Emotionally, the widow suffers stress, depression and fear because her partner is dead and the property is seized by the husband's relatives. The psychological implications of widowhood cultural practices according to Iwuh (1998) in Amalu (2013:84) are seen in Igbo society where widows undergo certain trauma in the name of widowhood practices. Such psychological trauma includes the widow being prevented from taking a bath, shaving her hair, going to the farm or market or engaging in any other activity until six months after her husband is buried. The practice of widows eating food without washing their hands and many other evil practices are being associated with widowhood.

\section{The place of the church}

The most basic interest of any church is centred on the humanitarian services of its members and the society. In Igboland, there are many churches, such as Catholic, Anglican, Methodist, Presbyterian, Pentecostal and African Independent Churches. According to Amalu (2013:111) in Christian teaching, the church activities for humanity include the value for human dignity and it has been the major responsibility of the churches to speak about the unfair cultural practices against women. The church not only condemned it but also put measures in place to alleviate the suffering of women in Igboland. These measures are discussed in the next section.

\section{Employment creation}

Employment is one of the ways of reducing poverty in the society. The Christian churches in Eastern Nigeria worked very hard to create employment for women especially the less privileged amongst them, like the widows who are being marginalised and maltreated in the society. Providing them with employment gave them authority to take control and make certain decisions on the things that concern them and their children. These were also acknowledged by Mbaga (2009:92) when he stated that the greatest role of the church in alleviating the unjust cultural practices against women in Igboland is by providing employment for the teeming population of widows.

\section{Empowerment}

Through the empowerment of women, the church forms the basis to change the practices and laws that discriminate against them, such as widowhood practices. The empowerment that the church offered to Igbo women is categorised into three major parts as noted by Amalu (2013:111). They are material empowerment, non-material empowerment and mobilisation empowerment.

\section{Material empowerment}

In material empowerment, the church provides the women with all the material things needed to empower them such as money, machinery and structures, etc. 


\section{Non-material empowerment}

Non-material empowerment involves enabling women to realise that their lack of status and welfare relative to men is not because of their inability but because of discrimination, culture and man-made norms, which give priority to men over women.

\section{Mobilisation empowerment}

This involves collective action by women to remove the discriminating practices against them by making proper use of the material empowerment given to them to create values for themselves.

\section{Education}

Education is known as a potent remedy for most of the ills in the society. It is the best instrument for women's liberation. When a woman is educated, she understands her world well. The church built missionary primary schools, secondary schools, teacher training colleges and recently higher institutions to hire women. As a result, women are now independent and play a significant role in decision-making.

\section{Taking care of widows}

According to Okoye (2001:23), widows undergo horrible experiences, which is blatant trampling on the rights of women of south-east Nigeria. These horrible experiences are concealed under the veil of traditional widowhood rituals and practices. In the past, the mourning period of a widow was one year and more, depending on her relationship with her in-laws, but recently it has been reduced to six months because of the combined effort of the churches.

\section{Recommendations}

In the study of the discriminatory cultural practices against women in Igboland, the researchers wish to make the following recommendations:

- The church should not relax all its efforts to help alleviate these unfair cultural practices because women are looking and are expecting more from them.

- The practice of bride price should be discouraged. It portrays women as goods, objects displayed in the market for purchase and when purchased, the buyer can do with it whatsoever he wants. Women are valuable and cannot be equated with commercial objects.

- Women whose rights are violated should be able to speak out so that necessary action can be taken early.

- Female circumcision should be discouraged, especially when the girl is still young, otherwise the consent of women should be sought before carrying it out. Therefore, female circumcision should be carried out when the girl is old enough to decide for herself if she really wants it to be performed.

- Religious groups in Nigeria should take it upon themselves to preach against the unjust cultural practices against women and stress the equality of all human beings before God.
- Non-governmental organisations (NGOs) and government should help reposition those affected by the abominable cultural practices by empowering them and making sure that there is proper monitoring to ensure the sustainability of the programmes.

- The federal, state and local governments should enact laws to curb these inhuman practices and punish offenders who violate these laws.

- The victims of these unfair cultural practices should be encouraged and supported. This is very important because these women are usually afraid and ashamed to disclose what has happened to them because of fear of being victimised as a result of the social stigma attached to it.

- There should be an enlightenment crusade against these practices using the bottom-top approach in the local government or rural areas where these practices are frequently perpetuated. The purpose of this enlightenment crusade should be to positively correct the attitudes and importance attached to these practices.

- The church will go a long way by changing people's mindset towards these practices, which were handed down to this generation by their forefathers because of lack of knowledge and ignorance. Education of women should be made compulsory to enable them to become enlightened and enrich themselves academically so as not to always be subdued by their male counterparts.

\section{Conclusion}

This article revealed that widowhood practices are inhuman cultural practices against women, which have constituted a serious health and psychological hazard against women. The practice of widowhood has persisted in some parts of Igboland, where it is firmly anchored in culture and tradition. In Nigeria, this practice is found to have a detrimental effect on the physical, psychological, emotional and social life of the widows. However, fear, superstition and poverty have been identified as the major obstacle to eliminate these practices irrespective of their negative implication on the society. Thus, the activities of the church in Igboland have been acknowledged for the great inputs in alleviating some of the sufferings of widows in Igboland. They gave not only spiritual assistance to widows but also material help, which go a long way to helping the widows and their children.

\section{Acknowledgements Competing interests}

The authors declare that they have no financial or personal relationships that may have inappropriately influenced them in writing this article.

\section{Authors' contributions}

All authors contributed equally to this work.

\section{Ethical considerations}

This article followed all ethical standards for research without direct contact with human or animal subjects. 


\section{Funding information}

This research received no specific grant from any funding agency in the public, commercial or not-for-profit sectors.

\section{Data availability}

Data sharing is not applicable to this article as no new data were created or analysed in this study.

\section{Disclaimer}

The views and opinions expressed in this article are those of the authors and do not necessarily reflect the official policy or position of any affiliated agency of the authors.

\section{References}

Adamu, F.L., 1999, 'A double-edged sword: Challenging women's oppression within Muslim society in Northern Nigeria', Gender \& Development 7(1), 56-61. https:// doi.org/10.1080/741922934

Amalu, C.T., 2013, 'The role of church in alleviating obnoxious cultural practices against women in Igbo Land', Unpublished PhD thesis, Department of Religion and Cultural Studies, University of Nigeria.

Bako, M.J. \& Syed, J., 2018, 'Women's marginalization in Nigeria and the way forward', Human Resource Development International 21(5), 425-443. https://doi.org/10. 1080/13678868.2018.1458567

Barlas, A., 2001, 'Muslim women and sexual oppression: Reading liberation from the Quran', Macalester International 10(1), 15.

Durkheim, E., 1915, The elementary forms of the religious life, Allen \& Unwin, London.

Ehirim, A., 2007, Ohuzo - Igbo ideals and socio-political thought, viewed 28 June 2007, from https://ohuzo.blogspot.com/search?q=chauvinist+assumptions.

Eudora, E.K., 2012, 'Women in national liberation wars in the settler colonies of Kenya and Zimbabwe: Pathways to political empowerment', Masters thesis, University of York, viewed 15 June 2021, from https://etheses.whiterose.ac.uk/2600/1/ Women_in_national_liberation_wars_Kenya_\%26_Zimbabwe.pdf.

Hafkin, N. \& Bay, E.G., 1976, Women in Africa: Studies in social and economic change, Stanford University Press, Stanford.

Illika, A.L., Okonkwo, I.P. \& Adogu, P., 2002, 'Intimate partner violence among women of childbearing age in a primary healthcare in Nigeria', African Journal of Reproductive Health 6(3), 1-12. https://doi.org/10.2307/3583257

Iwuh, C.A., 1998, 'Women matrimonial home', in Amalu, C.T., 2013, 'The role of church in alleviating obnoxious cultural practices against women in Igbo Land', An unpublished PhD thesis submitted to the Department of Religion and Cultural Studies University of Nigeria, Nsukka.
Mbaga, G.S., 2009, The church and employment, Parlour Publication, Lagos.

Mbagwu, F.O., 2009, 'Assessment of the harmful cultural practices affecting the health of rural women: A study of community based women organisations in Ebony State', A Ph.D thesis presented to the Department of Adult Education and ExtraMural Studies University of Nigeria, Nsukka.

Njaka, E., 1975, 'Igbo political institutions and transition', in Amalu, C.T., 2013, 'The role of church in alleviating obnoxious cultural practices against women in Igbo Land', unpublished PhD thesis submitted to the Department of Religion and Cultural Studies University of Nigeria, Nsukka.

Ntozi, N.P.M., 1977, 'Widowhood, remarriage and migration during the HIV/AIDs epidemic in Uganda', in Amalu, C.T., 2013, 'The role of church in alleviating obnoxious cultural practices against women in Igbo Land', An unpublished PhD thesis submitted to the Department of Religion and Cultural Studies University of Nigeria, Nsukka.

Nwadinobi, E., 2001, 'Introductory presentations at the widows without rights conference, fighting back against Prejudice and Discrimination', in Amalu, C.T., 2013, 'The role of church in alleviating obnoxious cultural practices 2013, 'The role in against women in lgbo land unpublished, An unpublished PhD thesis submitted to the Department of Religion and Cultural Studies University of Nigeria, Nsukka.

Nweze, A. \& Takaya, B.J., 2001, 'Relative deprivation of the Nigerian female personality as gender violence: A Nigerian overview', Paper presented at the workshop on Gender Violence and Poverty, Hill Station Hotel, Jos, Nigeria, 11th - 13th July, 2001, viewed 22 June 2021, from https://www.cbe.org.au/ 11 th -13 th July, 2001, viewed 22 June 2021, from https://www.cbe.org.au/
social-justice-for-women-and-girls-in-africa-issues-challenges-ministrystrategies/.

Odunze, A., 2005, The concept of widowhood, Dunnze Family Life Publishers, Enugu.

Okali, D., Okpara, E. \& Olawoye, J., 2001, The case of Aba and its region, southeastern Nigeria, viewed 21 April 2021, from https://www.jstor.org/stable/ resrep01762.5?seq=1\#metadata_info_tab_contents.

Okoye, P., 1985, Widowhood: A natural or cultural tragedy, Nucik Publishers, Enugu.

Onuogu, C.M., 2013, Culture and human development of education in Nigeria, African Publication, Onitsha.

Orjinta, I.A., 2011, Women's oppression, suppression and repression in Islam - A total blockade to their leadership quest, viewed 03 May 2021, from https://www.grin. com/document/168190.

Para-Mallam, F., 2010, Social justice for women and girls in Africa: Issues, challenges \& ministry strategies, viewed 15 June 2010, from https://www.cbe.org.au/ social-justice-for-women-and-girls-in-africa-issues-challenges-ministrystrategies/.

Rubenstein, M.J., 2004, 'An Anglican crisis of comparison: Intersections of race, gender, and religious authority, with particular reference to the Church of Nigeria', Journal of the American Academy of Religion 72(2), 341-365.

Saba, O., 1997, 'Psychological effects of widowhood on women and children', in Amalu, 2013, 'The role of church in alleviating obnoxious cultural practices against women in Igbo Land', Unpublished Ph.D thesis.

Unabuike, K.C., 2009, 'The value of poverty among African', Women Journal of Economic Improvement 63(1), 1-12.

World Health Organization (WHO), 2020, Declaration on the elimination of violence against women, viewed 22 June 2021, from https://www.ohchr.org/en/ professionalinterest/pages/violenceagainstwomen.aspx. 